\title{
スプリットビーム方式と小型水槽を用いる小型生物の ターゲットストレングスの測定方法
}

\author{
甘糟和男, 古澤昌彦, * 樊＼cjkstart春明
}

(2002年 9 月 9 日受付, 2003 年 1 月 29 日受理)

東京水産大学海洋生産学科

A method for target strength measurement of small-size animals by split-beam method in small tank

\section{KAZUO AMAKASU, MASAHIKo FURUSAWA* AND CHUMING FAN}

\author{
Department of Marine Science and Technology, Tokyo University of Fisheries, Minato, Tokyo 108-8477, Japan
}

\begin{abstract}
We developed a precise method for target strength (TS) measurement of small-size animals such as krill in a water tank. The measurement system consists of a $70 \mathrm{kHz}$ split-beam system and a video camera system to observe the orientation of animals. The transducer was set pointing downward on the top of the small tank with a window on one of the side walls for observing orientation. TS measurement and orientation observation are performed simultaneously. This system can avoid external disturbances such as wind and waves and be set up easily for measurements including measurement on board a ship. TS measurement for a physical model (copper cylinder) was conducted and the measured TS was in good agreement with the theoretical result, showing the accuracy of our method. Next, TS measurements of live shrimps were conducted to get detailed TS patterns. We compared the measured results with the theoretical TS patterns and confirmed a reasonable agreement.
\end{abstract}

キーワード : スプリットビーム方式, 小型水槽, ビラ゙オカメラ, オキアミ類, ターゲットストレングス (TS), TSパターン

ナンキョクオキアミやツノナシオキアミなどのオキア ミ類は，魚類や鯨類などの主要な䬣生物であり，また海 洋の食物連鎖において, 植物プランクトンの基礎生産を 大型生物へ運ぶという重要な役割を担っている。さら に，オキアミ類は，海洋生態系に打ける重要性だけでな く, 釣䬣や養殖用の䬣などの漁業資源としても重要であ り，事実オキアミ類の生産額は毎年多額に昇ってい る。1) 本論文に抢ける測定対象の小型生物は, 主にこの ようなオキアミ類である。

このような重要性からオキアミ類の資源調査や生態調 查が必要とされている。その調査手法の一つとして, 計 量魚群探知機（計量魚探機）などを用いた音響的手法が 効果的に適用されてきた。例えば，2000 年には南極海 洋生物資源保存委員会（CCAMLR）によるナンキョク オキアミ資源国際共同調査 ${ }^{2}$ が行われた。この国際共同 調査に抢いても，計量魚探機を用いた音響資源調查が中 心的な調査であった。また，我が国に㧍いては，三陸，
常磐沖におけるツノナシオキアミの漁場調査が魚群探知 機やソナ一等を用いて行わ扎ている。3,4)

音響水産資源調査では, 得られた音響データ (平均体 積散乱強度）を最終的な資源量に換算する際に，1個体 あたりの音響反射強度であるターゲットストレングス (TS）が重要なスケールファクタとなる。自然状態で は，TSが遊泳姿勢によって変化するので，遊泳姿勢に 対して平均したTS (平均TS) が必要となる。正確な 平均 TS の值を知るには, 遊泳姿勢に対する TS の特性 (TSパターン) を知る必要がある。

オキアミ類のような小型生物に対する TS 測定方法も 進歩してきてはいるが，依然としてその TS 測定は難し く，TSパターンの測定例は少ないのが現状である。こ の理由として以下のような点があげられる。オキアミ類 は, 1) 寸法が小さく, 弱く, 骨が無く, 形状が複雑で あるので, 取り扱いが難しく, 例えば魚のTS 測定の上 うな釣系による姿勢の制御 5 が難しいこと，2)小さく，

* Tel : 81-3-5463-0481. Fax : 81-3-5463-0518. Email : frsw@tokyo-u-fish.ac.jp 
鰾がないのでTSの值が小さいこと，3)鰾がなく，形状 が複雑であるので TSパターンが複雑であること，4)生 きた状態でのサンプルもしくはそれと同等の新鮮なサン プルの入手が難しいこと。

これまでのオキアミ類などを対象としたTSの測定方 法は，以下のように整理できる。1)ネットケージに複 数個体を収容して測定するケージ法, ${ }^{6-8)} 2$ ) 大型の水槽 内に送受波器を設置し, 単一個体を測定する方法, ${ }^{9-17)}$ 3)円筒型のケージ内，もしくは水槽内に扮いて，単一 個体を自然に近い状態で測定する方法。18-20)

ケージ法は, 複数個体に対して測定を行うことで十分 な信号対雑音比（SN 比）が得られる。また, 姿勢が適 当に分散し, 結果的に背方向平均 TS が比較的容易に推 定できる。よって便法としては優れている。7)

他の方法では，送受波器と測定個体との距離を近く し，単一個体に対する測定を行う。単一ビームを用いた 測定方法9-17)では，指向性の影響を除去するために，測 定個体を釣系でビーム軸に固定する必要があるが，指向 性を補正できるスプリットビーム（SB）万式やデュア ルビーム (DB) 万式を使用した測定方法 ${ }^{18,19)}$ では, 測 定個体に釣系を手綱のようにつけ，より自然に近い状態 での測定が可能である。単一ビームであっても, デコン ボリューション法を用いることにより，測定個体が自由 に遊泳した状態で測定できる方法20)がある。

姿勢特性を明らかに出来る方法としては，単一ビーム により TS 測定を行い，TS 測定中の測定個体の遊泳姿 勢をビデオカメラで観測することで，TSパターンを得 る万法が報告されている。 ${ }^{15)} \mathrm{SB}$ 万式や DB 方式を用い たTSパターンを得る方法は未だ例がない。

測定環境としては，海中にケージを設置する方 法6-8,18,19) では，風波や潮流といった外乱の影響や他生 物の混入による誤差などが避けられないが，水槽を用い る方法 ${ }^{9-17,20)}$ では，その点を回避できる。しかし，もし 大型の水槽を用いると，その設置場所が限られ，活きの よいサンプルが得やすい船上に置くなどの機動的測定が 不可能になり, 大量の海水を要し, かつ対象の正確な姿 勢観察を行なうのが困難になるといった問題点がある。

そこで, 本研究では, オキアミ類のような小型生物の TSパターンを，高精度かつ比較的容易に測定できる方 法を開発することを目的とする。観測空が備わった小型 の水槽を使用することで，姿勢観測を精確に行い，か つ，音響計測との同時計測を容易にする。さらに，SB 万式を使用することで, ビーム軸へ固定する必要を無く し，より自然に近い状態での測定を可能とする。また， $\mathrm{SB}$ 方式で得られる測定個体の位置情報は, 姿勢角測定 にも用いることで従来の姿勢角測定方法を拡張する。

まず，小型水槽を用いる高精度 TS パターン計測シス テムを構築し, 測定方法を確立する。次に, 物理モデル
（銅円筒）を測定対象とした検証実験を行い，測定方法 が妥当であることを確認する。さらに，本方法を実際に 生きた小型生物に適用し，有効性を検討する。

\section{方法}

計測システムの概要 計測システムの概要をFig. 1 に示す。計測システムは, SB方式による音響計測シス テムと, ビデオカメラによる姿勢観測システムとで構成 される。姿勢観測を精確に行い, かつ, 音響計測との同 時計測を容易にするために, 観測空が備わった小型水槽 $(1 \mathrm{~m} \times 1 \mathrm{~m} \times 1 \mathrm{~m})$ を使用した。送受波器は小型水槽上 面に下向きに設置した。

後処理の段階で，音響計測システムと姿勢観測システ ムの両データを対応させられるように，オシロスコープ とビデオカメラの時刻同期を取った。

音響計測システム一般に TS を測定する場合, 指向 性の影響を考慮しなければならない。単一ビームでは， 測定個体が送受波器に対してどの方向にいるのか分から ないので，測定個体をビーム軸に懸垂するなどして，指 向性を考えなくてよいようにする。しかし，才キアミ類 などの小型生物では，ビーム軸へ測定個体を固定する難 しさがあり，また，実際にビーム軸にあることを確認す る必要がある。さらに, 固定することによって測定個体 に不自然さが生じる。例えば，テグスで体のある部分を 固縛すれば，そこを中心とする運動しかできなくなる。 そこで, 本システムでは, 測定個体をビーム軸に固定す る必要のない SB 方式を用いることによってこの制限を 緩和し, ビーム内で動ける, より自然に近い状態で, 精 確な TS 測定ができるようにした。

Fig. 2 に音響計測システムのブロック図を示す。SB 方式を用いているので，1つのエコーレベル計測用ビー ム（レベルビーム）と，4つの位相計測用ビーム（位相 ビーム）の各信号を処理する必要がある。そのために， 2 台のディジタルオシロスコープを使用した。測定個体

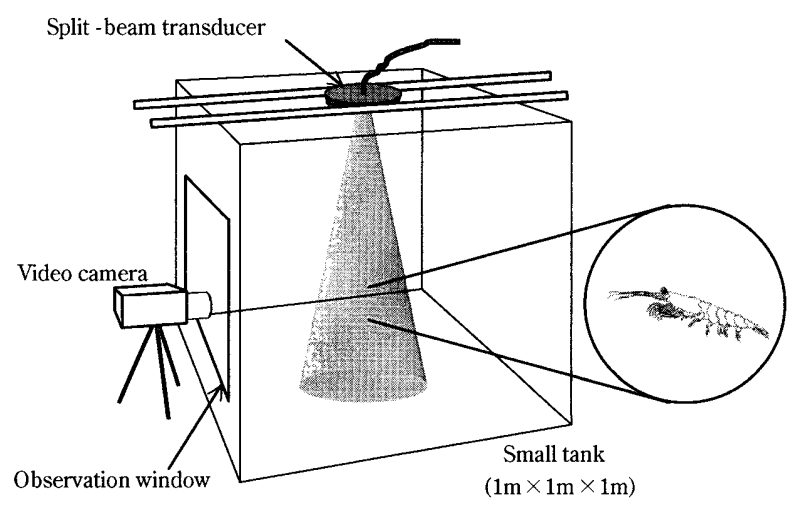

Fig. 1. Target strength measurement system using the split-beam method and a small tank. 


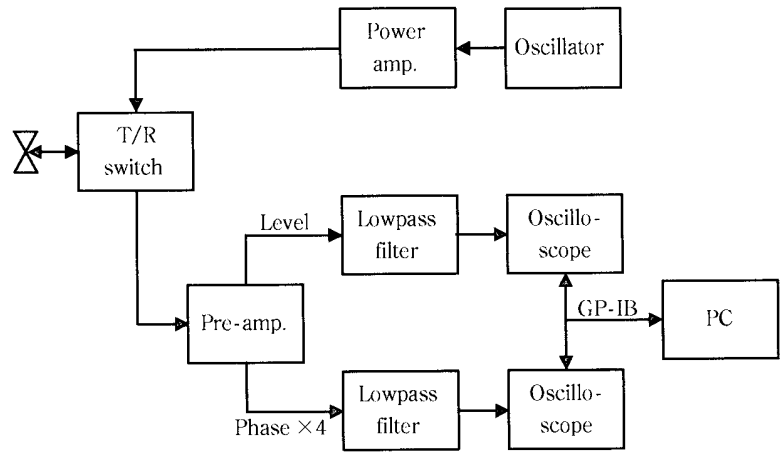

Fig. 2. Block diagram of the acoustic system.

Table 1. Specifications of the acoustic system.

\begin{tabular}{cc} 
Frequency $\quad[\mathrm{kHz}]$ & 70 \\
Beam width $\quad[\mathrm{deg}]$ & \\
Level beam & 19.8 \\
Phase beam & 11.8 \\
Pulse duration $\quad[\mathrm{ms}]$ & 0.3 \\
\hline
\end{tabular}

は遊泳姿勢を時々刻々と変化させるので, 2 台のオシロ スコープを PCにより GP-IB で制御し，データの連続 収録を行った。ローパスフィルタはカットオフ周波数を $100 \mathrm{kHz}$ とし, 雑音を低減した。

Table 1 に使用した音響計測システムの緒元を示す。

一般に，測定個体の体長に対して波長が短い高周波で はTSパターンは鋭く複雑になるため, 平均 TS の変動 も大きくなり, 量推定の精度が低くなる。しかし, 逆に 体長に対して波長が長い低周波ではその変動は小さいが, TSの值そのものが小さくなる。また，極端に低周波に なるとレイリ一領域となり，TSは体長の 6 乗に比例す るため，正確な体長分布がわかっていないと，TSの推 定には大きな䛊差を含むことになる。21)これまでの，才 キアミ類の音響資源調査では国際的に $120 \mathrm{kHz}$ （音速 $1500 \mathrm{~m} / \mathrm{s}$ とした時の波長 $1.25 \mathrm{~cm}$ ）功使用されてきた が，前述した理由により，オキアミ類のサイズに対して 波長が短いために TSの変動が大きい可能性がある。逆 に，計量魚探機の標準的な周波数である $38 \mathrm{kHz}$ (同 $3.95 \mathrm{~cm})$ では，才キアミ類の体長に対して波長が長い ので好ましくない。そこで，本システムでは以上の点を 考慮し, 中間的な周波数である $70 \mathrm{kHz}$ (同 $2.14 \mathrm{~cm}$ ) を使用した。

送受波器には, 計量魚探機（㹯力イジョー製 $\mathrm{KFC}-$ 1000 型）用のものを使用した。この送受波器は，SB 方 式以外に DB 方式にも対応しており，指向性の異なる狭 ビームと広ビームの 2 種類を実現できる。ビーム幅は それぞれ，8.4ㄴ $19.8^{\circ}$ である。通常，狭ビームで送波 を行うが，本方法では近距離での計測であるため，狭
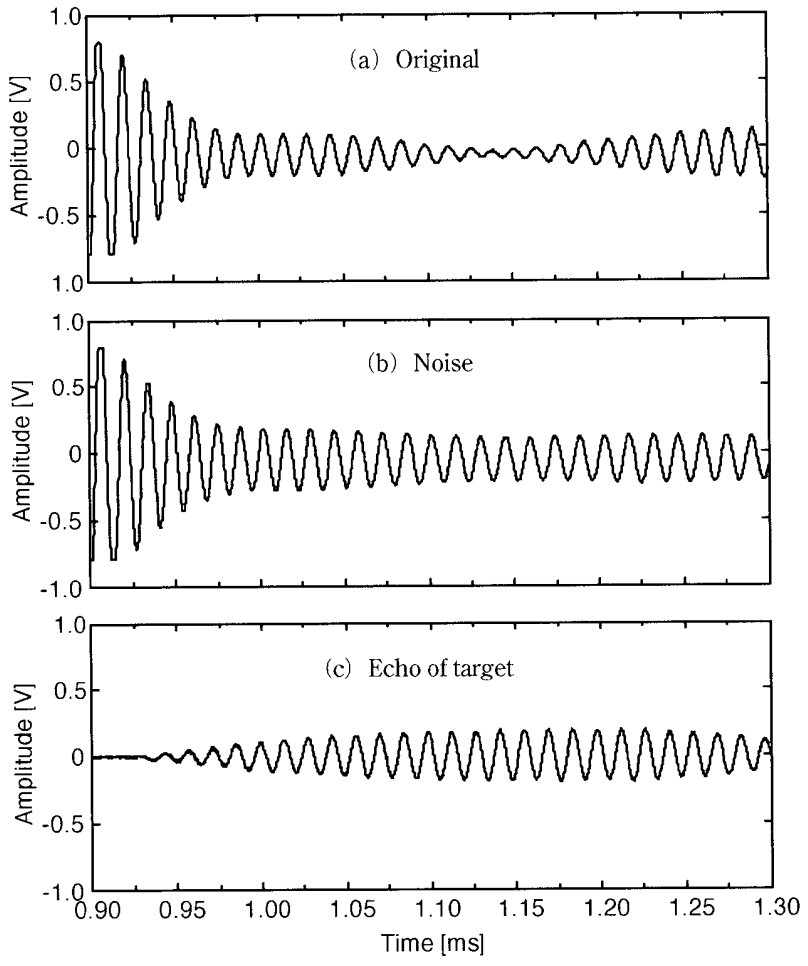

Fig. 3. Coherent reduction of noise (b), from original signal (a), to get echo of target animal (c).

ビームでの送波では，測定範囲が狭く，測定個体が移動 した時にビームから外れる機会が多い。そこで，広ビー ムをレベルビームとした。

広ビームで送波を行い，エコーレベルは広ビームで計 測し，位相差の測定では，エコーを前後左右に 4 分割 された位相ビームで受波し, 前後方向, 左右方向の位相 差を測定する。

水槽を小型（本研究で用いる水槽は $1 \mathrm{~m}$ 立法）にす ると，ビーム幅を広くすることにより水槽内壁からの不 要反射が増す。また，近距離での測定のために送波時の 残響が問題となる。小型生物のエコーは微弱であるの でこれらの不要反射や残響によるノイズにより測定個 体のエコーを簡単に確認し取り出すことが出来ない。そ こで，ノイズは以下に述べるようにコヒーレント減 算22)を行うことにより消去した。Fig. 3(a)のように， 収録するエコーは，测定個体のエコーとノイズを含んで いる。そこで，TS 測定前，もしくは測定後に，測定個 体のない状況でノイズのみを収録して抢く（Fig. 3 (b)）。後処理で，収録したエコー(a)から測定前（場合 によっては後）のノイズ(b)を送波時点を揃えて引くこ とで，測定個体のエコーのみを得ることができる（Fig. $3(\mathrm{c}))$ 。この図で $1.3 \mathrm{~ms}$ (深さ $97.5 \mathrm{~cm}$ ) 以降は, 水槽 底の大きなエコーによって対象のエコーは復元できな w。 
送受信系の較正は，TS 測定前に直径 $38.1 \mathrm{~mm}$ のタン グステンカーバイド製標準球を用いて行った。23) 標準球 の TS は, 水温の測定により音速を求め, 音速と TS の 関係から求奴（水温によって变わるが約 $-41 \mathrm{~dB}$ )。 送波音圧，受波感度，Fig. 2のフィルタ屯での利得の 3 者の積を送受信係数とし，これを較正したところ，約 $50 \mathrm{~dB}$ であった。

姿勢観測システム ビデオカメラ (SONY Handycam, DCR-TRV7, 68 万画素，以下カメラと呼ぶ）は, 観測空に密着させ，TS 測定中の測定個体の姿勢を録画 する。後処理で，次に述べる姿勢角測定方法により姿勢 角を算出する。従来は, カメラに対して測定個体が平行 である時しか姿勢角を求めることが出来なかった。そこ で, McGehee et al.の方法15)を, SB 方式の特長を活か すことで発展させ，この問題を解決した。

Fig. 4 に示すように， $\vec{a}$ を測定個体の向きを表す頭胸 部の末端から目の後端までを結ぶべクトルとする。尾節 の先端から目の後端までを結ぶベクトルを $\vec{a}$ とすること も考えられるが，その場合，腹部を屈曲させた場合とそ うでない場合では， $\vec{a} か ゙$ 異なり姿勢角の定義があいまい になる。また， $k$ を測定個体への音波の入射の波数べク トルとする。音波の入射方向に対して頭を上げている時 を正，下げている時を負とすると，姿勢角 $\theta_{t}$ は，次式 で求めることができる。

$$
\theta_{t}=-\frac{\pi}{2}+\cos ^{-1}\left(\frac{\vec{a} \cdot \vec{k}}{|\vec{a}||\vec{k}|}\right)
$$

したがって， $\theta_{t}$ を求めるためには $\vec{a}, \vec{k}$ が必要である。

まず， $\vec{a}$ を求める。Fig. 5 の上うに，送受波器中心を 原点とした座標系を $\mathrm{X}, \mathrm{Y}, \mathrm{Z}$ (大文字) で表し， $\vec{a}$ の始 点を原点とした座標系を $\mathrm{x}, \mathrm{y}, \mathrm{z}$ (小文字) で表す。 $\mathrm{SB}$ 方式用の送受波器は，測定対象の方位を測定する関係で 設置方向が重要であり, 前 (fore), 後 (aft), 左 (port), 右（starboard）の方向が決められている。本システム では，図のように X を前方向，Yを右方向となるよう に設置した。

カメラは，カメラ軸が $Z$ 軸（ビーム軸）に対して垂 直となるように, $\mathrm{YZ}$ 面上の $-\mathrm{Y}$ 方向へ向けて設置す る。カメラ軸からのずれによる画像の大きさの違いは検 知できない程度であったので，歪みもほとんどないと考 えられる。測定個体からカメラまでの距離を考える場合 は, カメラ軸と $\mathrm{y}$ 軸が一致しているものとして考える

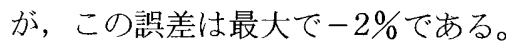

$\mathrm{xz}$ 面に投影された $\bar{a}$ の成分 $\left(a_{x}, 0, a_{z}\right)$ は画像から確 認できる。画像上でのこの成分を $\left(a_{x v}, 0, a_{z v}\right)$ とする。 測定個体からカメラまでの距離が測定個体の動きによっ て変化するので， $a_{x v}, a_{z v}$ の值も変化する。ビーム軸に 測定対象がある場合を基準とすると，この变化はビーム 軸からカメラまでの距離 $Y_{v}$ に対する測定個体からカメ

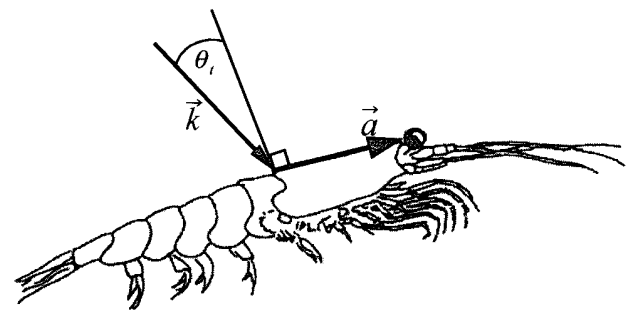

Fig. 4. Definition of the orientation angle $\theta_{t}(\vec{a}$ : body orientation vector, $k$ : incident wave number vector).

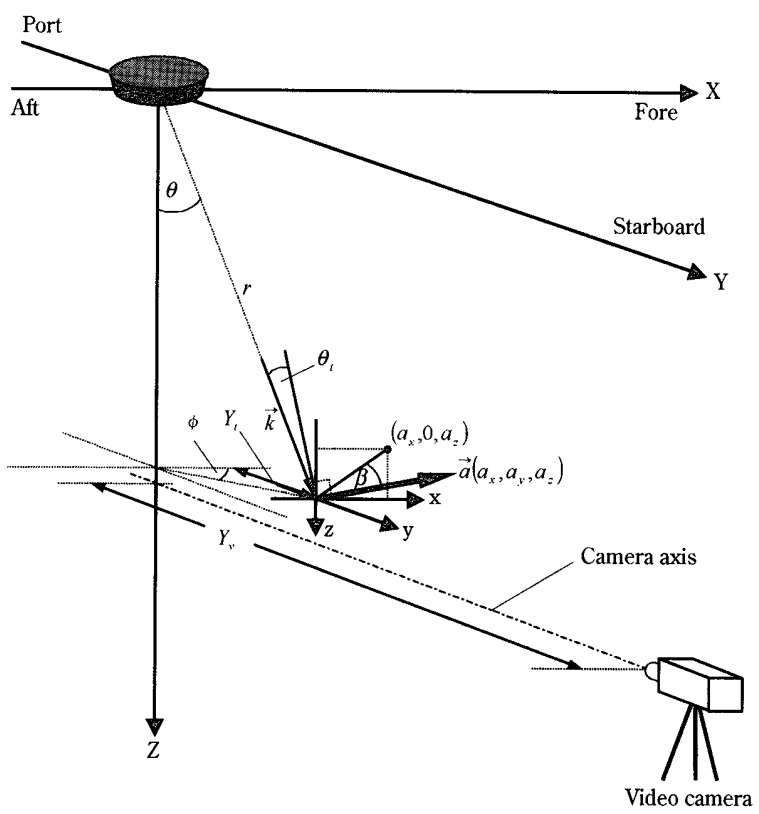

Fig. 5. Geometrical view of the measurement system. Details are given in the text.

ラまでの距離 $\left(Y_{v}-Y_{t}\right)$ の比で表すことができる。よ って, 次式により実際の $a_{x}, a_{z}$ を求める。

$$
\begin{aligned}
& a_{x}=a_{x v}\left(\frac{Y_{v}-Y_{t}}{Y_{v}}\right) S \\
& Y_{t}=r \sin \theta \sin \phi
\end{aligned}
$$

ここで， $Y_{v}$ はビーム軸からカメラまでの距離， $Y_{t}$ は $\mathrm{XZ}$ 面から $\bar{a}$ の始点までの距離である。 $Y_{v}$ は, あらか じめ計測して扔くことで求まり, $32.5 \mathrm{~cm}$ であった。 $Y_{t}$ はSB 方式により測定個体の位置 $(r, \theta, \phi)$ が分かるの で，(3)式により求まる。また，S はビーム軸に扔ける 単位画素あたりのサイズであり，ビーム軸に銅円筒（長 さ $3.0 \mathrm{~cm}$, 直径 $0.4 \mathrm{~cm}$ ）をカメラに対して平行に吊る し, その画像から $0.0441 \mathrm{~cm} / \mathrm{pixel}$ となった。 $a_{z}$ を求め る場合は，(2)式において，添え字の $x$ を $z$ とすればよ い。

$a_{y}$ は， $\vec{a}$ が $\mathrm{xz}$ 面に投影された直線と $\vec{a}$ とがなす角度 を $\beta$ とすると次式より求まる。

$$
a_{y}=|\vec{a}| \sin \beta
$$




$$
\beta=\cos ^{-1}\left(\frac{\sqrt{a_{x}^{2}+a_{z}^{2}}}{|\vec{a}|}\right)
$$

$|\vec{a}|$ は，実際に頭胸部の長さを計測することで求まる。 以上の 3 成分により $\vec{a}$ が求まる。

$\vec{k}$ は, SB 万式により位置角 $(\theta, \phi)$ が分かるので, 下式により各成分が求まる。

$$
\vec{k}=|\vec{k}|\left(\begin{array}{c}
\hat{k}_{x} \\
\hat{k}_{y} \\
\hat{k}_{z}
\end{array}\right)=|\vec{k}|\left(\begin{array}{c}
\sin \theta \cos \phi \\
\sin \theta \sin \phi \\
\cos \theta
\end{array}\right)
$$

ここで， $\lambda$ を波長として $|\vec{k}|=2 \pi / \lambda$ である。

以上により， $\bar{a}, \vec{k}$ が求まるので，(1)式によって $\theta_{t}$ が 求まる。これと，SB方式により得られる TS 值を組み 合わせて，TSの $\theta_{t}$ 特性，すなわち TSパターンが得ら れる。

測定方法の検証 理論によって TS 計算が可能な物理 モデルを測定対象としたTS 測定を行うことにより，測 定方法が妥当であるかを検証した。物理モデルには，銅 製の円筒（長さ $3.0 \mathrm{~cm}$ ，直径 $0.4 \mathrm{~cm}$ ）を用いた。銅は, 標準球の材質としても用いられており，24,25) 材質が錆び にくく，純粋であり，有限円筒散乱の理論モデル26)の 計算に必要なパラメータも既知である。 用した物理モデルの緒元を示す。

銅円筒に釣系を接着し，あらゆる傾角で懸垂し TS 測

Table 2. Parameters used in the copper cylinder model calculations.

\begin{tabular}{lc}
\hline Measurement date & \multicolumn{1}{c}{$11 / 28 / 2000$} \\
Material & Copper \\
Shape & Finite straight cylinder \\
Length $[\mathrm{cm}]$ & 3.0 \\
Diameter $[\mathrm{cm}]$ & 0.4 \\
Longitudinal wave sound speed ${ }^{25)}[\mathrm{m} / \mathrm{s}]$ & 4760.0 \\
Transverse wave sound speed ${ }^{25)}[\mathrm{m} / \mathrm{s}]$ & 2288.5 \\
Density of copper 25$)\left[\mathrm{g} / \mathrm{cm}^{3}\right]$ & 8.947 \\
Water temp. $\left[{ }^{\circ} \mathrm{C}\right]$ & 14.5 \\
Sound speed of water $[\mathrm{m} / \mathrm{s}]$ & 1483.2 \\
Density of water $\left[\mathrm{g} / \mathrm{cm}^{3}\right]$ & 1.000 \\
\hline
\end{tabular}

定を行った。測定の際には，せっけん水で表面を拭い， 気泡が付着しないように注意した。

小型生物の TS 測定＼cjkstart構築した計測システム抢よび測 定方法を小型生物に対して適用し，オキアミ類のような TSの小さい小型生物の TSパターンが得られるかを検 証した。

最初の試みとして，2000 年 12 月 17 日，浮遊性の工 ビであるトガリサクラエビ Sergia creberの TS 測定を行 った。トガリサクラエビは，東京水産大学練習船青鷹丸 にて, IONESS (Intelligent Operative Net Sampling System, 網口面積 $\left.1 \mathrm{~m}^{2}\right)$ により相模湾の水深約 400 $600 \mathrm{~m}$ から採集した。採集後, 生きた状態のまを東京水 産大学の研究室に持ち帰り, 即座に 4 個体の TS 測定を 行った。測定個体は，ビーム内の適当な位置にとどまる ように釣系によって簡単に拘束するのみで, 自ら浮遊, 遊泳し，姿勢を変化させた。次に，2001 年 10 月には， 東京水産大学練習船海鷹丸に計測システムを積み込み, RMT (Rectungular Midwater Trawl, 網口面積 $8 \mathrm{~m}^{2}$ ) により採集した浮遊性エビ類の TS 測定を行った。

しかし，これらの測定值と後述する理論モデルによる TSパターンとの比較では良い一致が見られず，約 10 $\mathrm{dB}$ の差が生じた。これは, 測定個体に気泡が付着して いたためと考えられた。さらに，オキアミ類や浮遊性工 ビ類は，水温変化に対して弱く，サンプリングネットに より採集する過程に打いて多くが死亡してしまい，十分 な量の海産の生きた小型生物を採集することは難しかっ た。以上のように，極力迅速に活きた小型生物を陸上の 研究室に運ぶ方法，抢よび，船上に水槽を含む計測シス テムを搭載する方法により，小型生物の TS 測定が可能 であることは確認できたが，一方で，気泡によると考え られる䛊差対策，活きのいいサンプルを豊富に得る方法 の課題が残った。

そこで，测定対象として，体の肉質や形状がオキアミ 類に類似している淡水産の小型エビであるスジエビ Palamon paucidens 孝生きた状態で用いた。Table 3 に 各個体の体長, 測定日, 測定時の水温と音速, 淡水の密 度, 理論モデルの計算に必要な媒質と体内との音速比抢

Table 3. Parameters used in the shrimp model calculations

\begin{tabular}{cccccccc}
\hline No. & $\begin{array}{c}\text { Body length } \\
{[\mathrm{cm}]}\end{array}$ & $\begin{array}{c}\text { Measurement } \\
\text { date }\end{array}$ & $\begin{array}{c}\text { Water temp. } \\
{\left[{ }^{\circ} \mathrm{C}\right]}\end{array}$ & $\begin{array}{c}\text { Sound speed } \\
\text { of water } \\
{[\mathrm{m} / \mathrm{s}]}\end{array}$ & $\begin{array}{c}\text { Density } \\
\text { of water } \\
{\left[\mathrm{g} / \mathrm{cm}^{3}\right]}\end{array}$ & $\begin{array}{c}\text { Sound speed } \\
\text { contrast }\end{array}$ & $\begin{array}{c}\text { Density } \\
\text { contrast }\end{array}$ \\
\hline $\mathrm{A}$ & 3.40 & $11 / 29 / 2001$ & 16.8 & 1471.3 & 1.000 & 1.0335 & 1.0626 \\
$\mathrm{~B}$ & 4.00 & $12 / 02 / 2001$ & 17.8 & 1474.6 & 1.000 & 1.0312 & 1.0626 \\
$\mathrm{C}$ & 3.83 & $12 / 03 / 2001$ & 19.2 & 1479.1 & 1.000 & 1.0281 & 1.0626 \\
$\mathrm{D}$ & 3.49 & $12 / 04 / 2001$ & 20.0 & 1481.6 & 1.000 & 1.0264 & 1.0626 \\
$\mathrm{E}$ & 3.58 & $12 / 06 / 2001$ & 20.0 & 1481.6 & 1.000 & 1.0264 & 1.0626 \\
$\mathrm{~F}$ & 3.20 & $12 / 08 / 2001$ & 19.0 & 1478.5 & 1.000 & 1.0285 & 1.0626 \\
\hline
\end{tabular}


よび密度比を示した。

今回, スジエビの音速比と密度比は求めなかった。そ こで, Footeのナンキョクオキアミについての実測值 ${ }^{27)}$ を, スジエビの TS 測定時における淡水の音速と密度の 条件に換算して用いた。Foote はナンキョクオキアミの 音速比を1.0279 と報告している。 ${ }^{27)}$ 文献より測定時の海 水の音速は $1479.3 \mathrm{~m} / \mathrm{s}$ であるので，体内音速は 1520.6 $\mathrm{m} / \mathrm{s}$ と計算される。そこで, スジエビの TS 測定時にお ける淡水の音速とナンキョクオキアミの体内音速との比 を求め, Table 3 の音速比とした。それぞれの音速比が 異なるのは, 測定時の水温によって, 水槽中での音速が 異なっていたためである。また，ナンキョクオキアミの 密度比は 1.0357 と報告されている。而前述した体内音速 測定時の水温, 塩分濃度より, 海水の密度を $1.0260 \mathrm{~g} /$ $\mathrm{cm}^{3}$ とすれば，体内密度は $1.0626 \mathrm{~g} / \mathrm{cm}^{3}$ である。スジ エビの TS 測定は淡水で行っているため, 淡水の密度を $1.000 \mathrm{~g} / \mathrm{cm}^{3}$ とし, その比を密度比とした。淡水の密度 は一定と考えたので, 密度比はすべての個体において 1.0626 とした。

使用した理論モデルは, DWBA (Distorted Wave Born Approximation）変形円筒モデル15,28,29)である。こ の理論モデルは, 散乱体の形状を円筒薄片のつながりと して考える。Table 3 に示した物理パラメータ以外に, 各円筒の半径とその中心座標がモデル計算に必要とな る。この形状データは, 測定中の測定個体がカメラに対 して平行になった時に撮影された，やや体を曲げた横向 きの典型的な姿勢の時のビデオ画像から求めた。円筒半 径は横向きのもの, すなわち体高から求めた。また, 観 察によれば，ロール方向の運動はせず，ほぼ脚側は下を 向いていた。

測定個体の懸垂方法をFig. 6 に示す。釣系を手綱の ようにつけ測定中にスジエビがビームから大きく外れて しまうことがないようにすると, スジエビは底生性であ るので, 水槽底へ向かう行動をとる。そこで, 腹脚を切 断し，遊泳能力を低下させ，姿勢を意図的に变化できる ように頭胸部と腹部に釣系を結び付けて懸垂した。これ らの前後 2 本の釣糸による制御は，スジエビが底生性 であるが故にやむなく行ったが，才キアミ類の場合は 1 本の釣系を手綱のように使用して, より自然に近い状態 で測定できる。この点は, 前述したトガリサクラエビな どによる洋上実験で確かめてある。スジエビの位置は ビーム軸から 3 から $4^{\circ}$ 以内に入るようにした。

小型生物のTS 測定において, 気泡の付着による影響 は大きく, 誤差要因の一つである。7,8) そこで, 本測定時 には気泡が付着しないように細心の注意を払い, 以下の ことを行った。1)釣糸を測定個体に接着させるのでは なく結んだ，2)結ぶための一連の作業を水の中で行っ た，3)測定開始前に気泡が付着していないことを確認

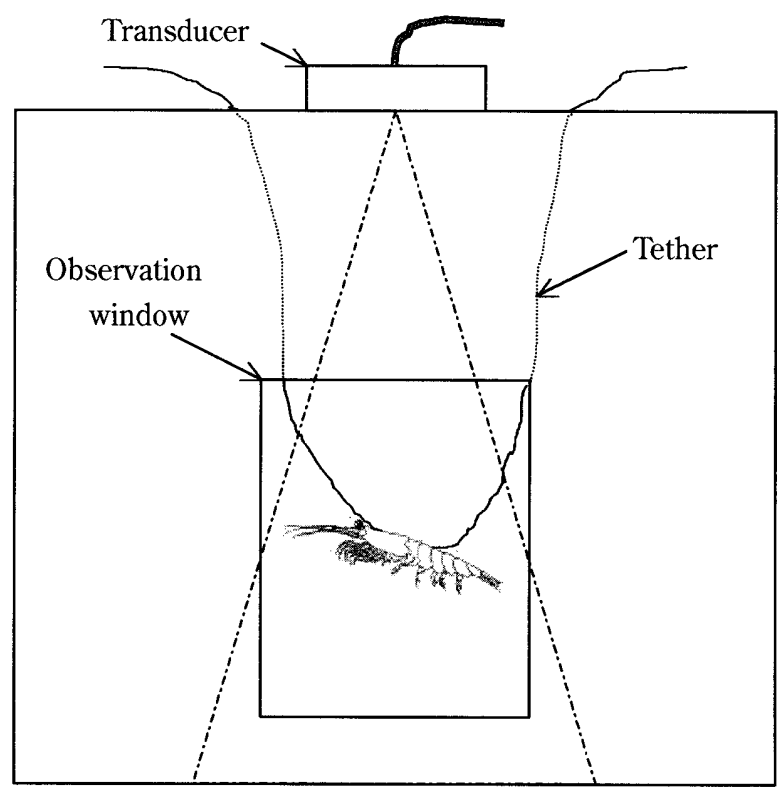

Fig. 6. Suspension method of a live shrimp.

し，付いていた場合には取り払ってから測定を開始し た。

\section{結果}

銅円筒の測定值と理論モデルによるTSパターンを Fig. 7 に示す。測定值と理論值の相関係数 $R$ は 0.96 で あった。測定值と理論モデルによるTSパターンがよく 一致していることが確認できる。これにより姿勢の測定 精度も高いことが検証された。

スジエビ 6 個体の測定值と DWBA 变形円筒モデルに よるTSパターンをFig. 8 に示す。測定值と理論値の 相関係数 $R$ を図中に示した。個体 $\mathrm{B} の 0.70$, 個体 $\mathrm{C}$ の 0.58 以外は 1 に近い值を示した。

個体 $\mathrm{A}$ は，幅広い $\theta_{t}$ で測定值が得られ，理論值とよ く一致した。 $\theta_{t}$ が $-20^{\circ} \sim-30^{\circ}$ の範囲で測定 TS が最も 低くなるが，これも理論モデルによる TSパターンとよ く一致している。個体 B の測定值は, 全体的にモデル と類似したTSパターンが得られたが，部分的に測定值 が理論值よりも大きい結果となった。個体 C は測定で きたデータ数が少なく, 全体的に理論値より過大となっ た。しかし， $\theta_{t}$ が $10^{\circ} \sim 30^{\circ}$ にかけての TS 值の変化 は，理論值とほぼ一致している。個体 $\mathrm{D}, \mathrm{E} は$ は, 相関係 数がそれぞれ $0.96,0,94$ と大きく, 理論值と大体におい て一致しているが，姿勢を意図的に変化できなかったた め, $\theta_{t}$ が負となる範囲で測定值が得られなかった。個体 $\mathrm{F}$ は, 幅広い $\theta_{t}$ で測定值が得られ，個体 $\mathrm{A}$ ほどではな いが理論値ともほぼ一致している。 


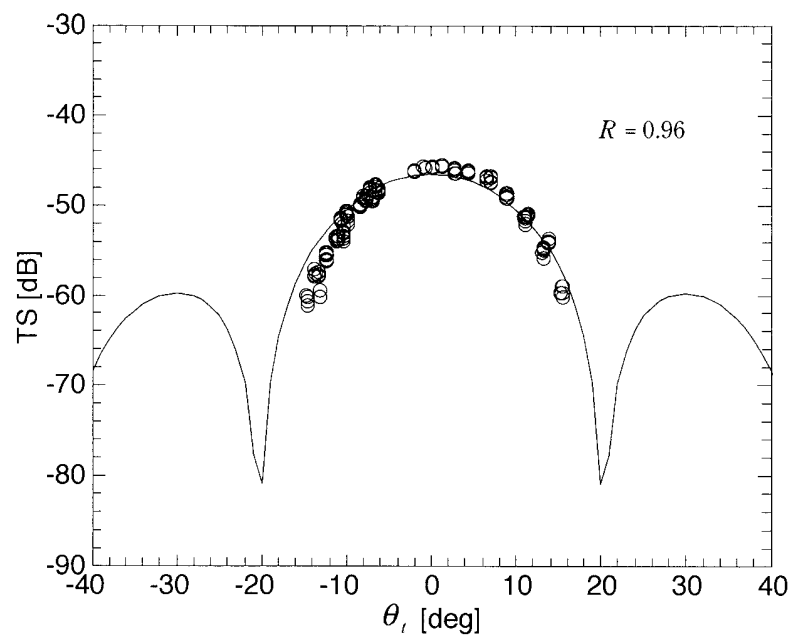

Fig. 7. Results from measurements and model calculation of TS pattern for copper cylinder $(3.0 \mathrm{~cm}$ long, $0.4 \mathrm{~cm}$ diameter). Physical parameters are listed in Table 2. Correlation coefficient, $R$, between measurement and model calculation is shown.


Fig. 8. Results from measurements and DWBA-based deformed cylinder model calculations of TS pattern for River shrimp (Palamon paucidens). Correlation coefficients, $R$, between measurement and model calculation are shown.
考察

銅円筒を用いた測定方法の検証では, 相関係数も 0.95 であり，測定值と理論モデルによるTSパターン がよく一致していることから, 測定方法が妥当であるこ とを確認できた。

スジエビ 6 個体を用いたTS 測定では，詳細な TSパ ターンが得られ, また, 測定值と理論值がほぼ一致し た。小型生物の TS と姿勢を精密に測定し, TSパター ンを得るための本計測システムおよび測定方法は有効で あることを確認した。

測定值と理論值が正確には一致しない理由として, 測 定個体に付着した取り切れなかった気泡による影響, 理 論モデルの計算に用いた音速比と密度比が実際とは異な っている可能性, 腹部の屈曲に伴う TS 変化などが考え られる。

気泡の付着による影響に関しては, 測定時には気泡が 付着しないような対策をし，細心の注意を払ったが，付 着していた可能性は拭いきれない。しかし，今回の結果 における測定值と理論值との差は, 前述したトガリサク ラエビの測定結果ほどは大きくはなかった。よって，気 泡が付着していた可能性は残るものの, 気泡が付着しな いようにするためにとった対策は有効であり，今後の TS 測定の際は同等以上の細心な対策をとる必要があ る。

音速比, 密度比に関しては, 個体 $\mathrm{A}, \mathrm{F}$ の測定值と理 論値がほぼ一致していることもあり，これらが大きく実 際と異なっていたとは考えにくい。測定個体の体内密度 と体内音速を精密に調べることで, より正確な理論モデ ルの計算を行うことができる。

オキアミ類やエビ類は, 腹部の屈曲に伴いTS が変化 する。実際に個体 F では, 測定中に腹部を屈曲させる ことがあった。 $\theta_{t}$ がー $20^{\circ} \sim-30^{\circ}$ 付近における測定值と 理論值の不一致は, 腹部の屈曲によるものと考えられ る。この点は理論モデルによって確かめた。30)

個体 $\mathrm{B} の 30^{\circ}$ 付近の不一致は, 頭胸部方向加 50 入射 であるので腹部の屈曲によるものとは考えにくい。この 原因は，現段階では明らかにできなかった。

本方法の一つの特長は小型水槽を用いることである。 これにより，風波や潮流といった外乱の影響や他生物の 混入を回避でき, 姿勢の観察を精度高く行え, 装置の設 置を容易に行うことが可能になった。また, 水槽は調査 船等に積み込むことのできる大きさであり，生物を採集 し, 生物が弱る前に, 静かな湾内, 岸壁などに停泊して いる際に，船上に扔いてTS 測定を行うことが可能にな った。

本研究では, SB 万式と小型水槽を用いた小型生物の TSの測定方法を開発した。本方法は, SB方式を小型 
水槽において使用し，正確かつ容易な測定ができるとい う，従来の測定方法にはない新しい方法である。また， ビーム幅の拡大や SB 方式の特長を生かした姿勢角测定 方法により，ほとんどすべての測定データを使用でき る。

今後は，本計測システムおよび測定方法を用い，南極 海に生息するナンキョクオキアミ，日本近海に打けるッ ノナシオキアミ等の TS 测定を行い, 詳細な TS パター ンを測定する。また，オキアミ類よりもさらにサイズが 小さいカイアシ類など，釣禾などによる制御が難しい小 型生物の TS 測定への応用が期待できる。

以下に研究結果ををとめる。

1）観測空が備わった小型水槽を用いることで, 姿 勢観測を精確に行い，かつ，音響計測との同時姿勢 計測が容易な方法とした。また，活きのよいサンプ ルの得られる船上での測定が可能である。

2）スプリットビーム（SB）方式を用いるために, 精確なターゲットストレングス（TS）測定を行う ことができ，ビーム軸に束縛する必要がないことか ら，自然に近い状態での測定が可能になる。オキア ミ類などの制御の難しい小型生物に対して有効であ り, 従来より自然に近い状態での TS 測定が可能に なった。また，SB方式の特長を指向性補正だけで なく，姿勢角測定にも生かすことで, McGehee et $a l$. の姿勢角測定方法 ${ }^{15)}$ を拡張した。

3）ビーム幅を広くすることで，測定個体が移動し た時にビームから外れることを少なくした。ビーム 幅の拡大に伴う不要散乱波は，コヒーレント減算に より消去できた。

4）銅円筒を用いた測定方法の検証実験により測定 方法が妥当であることを確認した。

5）生きた状態のスジエビを用いた TS 測定では，詳 細なTSパターンが得られた。測定值と理論值がほ ぼ一致し，小型生物の TS 測定に有効であることを 確認した。

\section{謝辞}

東京水産大学海洋環境学科の石丸隆教授, 東京水産大 学練習船海鷹丸の小池義夫船長, 同じく青鷹丸の峰雄二 船長（現神鷹丸船長）および乗組員の方々には，小型生 物の採集, 船上での実験に際し, ご協力, ご助言を頂き ました。ここに記して感謝申し上げます。東京水産大学 大学院 (当時) の浜田光利氏には, 本研究を進めるにあ たりご指導とご協力を頂きました。深く感謝申し上げま す。その他多くの方々のご協力を仰ぎました。心より感 謝致します。

\section{文献}

1) Nicol S, Endo Y. Krill fisheries of the world. FAO Fish. Tech. Pap. 1997; 367: 1-100.

2) 永延幹男, 川口 創, 龟田卓彦, 高尾芳三, 井口直樹, $1999 / 2000$ 年開洋丸南極海オキアミ生態系調査. 遠洋 2000; 106: 18-22.

3）宮城県水産研究開発センタ一. オキアミ通報第 $1 \sim 3$ 報. 平成 11 年度漁海況調査報告書, 宮城県水産研究開発セ ンター，宮城. $2000 ; 181-185$.

4）安藤隆二, 横須賀功, 豊島征司. ツノナシオキアミの漁 期前 - 漁期中漁場調査. 茨城県水産試験場事業報告平成 12 年度, 茨城県水産試験場, 茨城. 2001; 103-112.

5) Sawada K, Miyanohana $Y$, Ishii K. Precise target strength pattern measurement in an indoor tank. J. Acoust. Soc. Jpn. (E) 1997 ; 18: 231-238.

6) Foote KG, Everson I, Jonathan L, Watkins JL, Bone DG. Taregt strengths of Antarctic krill (Euphausia superba) at 38 and $120 \mathrm{kHz}$. J. Acoust. Soc. Am. 1990; 87: 16-24.

7）宮野鼻洋一。魚のターゲットストレングスの特性に関す る研究. 博士論文, 東京水産大学, 東京. 1992.

8）宮下和士. 音響的手法を用いた動物プランクトンの分布 抢よび量推定に関する研究. 博士論文, 東京大学海洋研 究所, 東京. 1996.

9) Greenlaw CF. Backscattering spectra of preserved zooplankton. J. Acoust. Soc. Am. 1977; 62: 44-52.

10) Kristensen $\AA$. Acoustic classification of zooplankton. $\mathrm{PhD}$ Thesis, The University of Trondheim, Trondheim. 1983.

11) Chu D, Stanton TK, Wiebe PH. Frequency dependence of sound backscattering from live individual zooplankton. ICES J. Mar. Sci. 1992; 49: 97-106.

12) Stanton TK, Wiebe PH, Chu D, Benfield MC, Scanlon L, Martin L, Eastwood RL. On acoustic estimates of zooplankton biomass. ICES J. Mar. Sci. 1994; 51: 505512.

13) Stanton TK, Chu D, Wiebe PH. Acoustic scattering characteristics of several zooplankton groups. ICES $J$. Mar. Sci. 1996; 53: 289-295.

14) Stanton TK, Chu D, Wiebe PH, Benfield MC, Scanlon L, Martin L, Eastwood RL. Sound scattering by several zooplankton groups. I. Experimental determination of dominant scattering mechanisms. J. Acoust. Soc. Am. 1998; 103: 225-235.

15) McGehee DE, O'Driscoll RL, Traykovski LVM. Effects of orientation on acoustic scattering from Antarctic krill at 120 kHz. Deep-Sea Research II 1998; 45: 1273-1294.

16) Traykovski LVM, O'Driscoll RL, McGehee DE. Effect of orientation on broadband acoustic scattering of Antarctic krill Euphausia superba: Implications for inverting zooplankton spectral acoustic signatures for angle of orientation. J. Acoust. Soc. Am. 1998; 104: 2121-2135.

17) Lavery AC, Stanton TK, McGehee DE, Chu D. Threedimensional modeling of acoustic backscattering from fluid-like zooplankton. J. Acoust. Soc. Am. 2002; 111: 1197 -1210 .

18) Wiebe PH, Grenne CH, Stanton TK, Burczynski J. Sound scattering by live zooplankton and micronekton: Empirical studies with a dual-beam acoustical system. J. Acoust. Soc. Am. 1990; 88: 2346-2360.

19) Demer DA, Martin LV. Zooplankton target strength: Volumetric or areal dependence?. J. Acoust. Soc. Am. 1995; 98: 1111-1118.

20) Pauly T, Penrose JD. Laboratory target strength meas- 
urements of free-swimming Antarctic krill (Euphausia superba). J. Acoust. Soc. Am. 1998; 103: 3268-3280.

21) Furusawa M, Miyonohana Y, Ariji M, Sawada Y. Prediction of Krill Target Strength by Liquid Prolate Spheroid Model. Fisheries Science 1994; 60: 261-265.

22) Ding L. Direct laboratory measurement of forward scattering by individual fish. J. Acoust. Soc. Am. 1997; 101: 3398-3404.

23）古澤昌彦, 宮野鼻洋一, 澤田浩一, 高尾芳三. 計量魚群 探知機の較正方法. 水産工学研究所技報 1995; 15: 9-37.

24) Foote KG, Knudsen HP, Vestnes G, MacLennan DN, Simonds EJ. Calibration of acoustic instruments for fish density estimation: A practical guide. Int. Coun. Explor. Sea Coop. Res. Rep. 1987; 144: 1-69.

25) Foote KG. Optimizing copper spheres for precision calibration of hydroacoustic equipment. J. Acoust. Soc. Am. 1982; 71: 742-747.
26) Stanton TK. Sound scattering by cylinders of finite length. II. Elastic cylinders. J. Acoust. Soc. Am. 1998; 83: 64-67.

27) Foote KG. Speed of sound in Euphausia superba. J. Acoust. Soc. Am. 1990; 87: 1405-1408.

28) Chu D, Foote KG, Stanton TK. Further analysis of target strength measurements of Antarctic krill at 38 and 120 $\mathrm{kHz}$ : Comparison with deformed cylinder model and inference of orientation distribution. J. Acoust. Soc. Am. 1993; 93: 2985-2988.

29) Stanton TK, Chu D, Wiebe PH. Sound scattering by several zooplankton groups. II. Scattering models. J. Acoust. Soc. Am. 1998; 103: 236-253.

30） 甘糟和男, 古澤昌彦, 谷 智明, 樊 春明. 才キアミ類 の体屈曲に伴うターゲットストレングスの変化. 海洋音 響学会講演論文集 2002: 25-28. 